\title{
PROFESIONALISME KEPEMIMPINAN KEPALA SEKOLAH (Kajian Konsep Dan Teoritis)
}

\author{
Nurmadiah \\ Dosen Manajemen Pendidikan Islam Univeristas Islam Indragiri
}

\begin{abstract}
Abstrak
Peningkatan Profesionalisme kepemimpinan kepala sekolah harus dilakukan melalui suatu strategi perbaikan mutu yang diharapkan dapat mengatasi masalah rendahnya mutu pendidikan dan dapat mengoptimalkan segala sumber daya yang terdapat di sekolah. Upaya peningkatan profesionalisme kepala sekolah merupakan proses keseluruhan dan bagian dari organisasi sekolah serta harus dilakukan secara berkesinambungan karena perubahan yang terjadi selalu dinamis serta tidak bisa diprediksi sehingga kepala sekolah maupun tenaga kependidikan harus selalu siap dihadapkan pada kondisi perubahan. Dalam perubahan peningkatan profesional kepala sekolah harus ada pihak yang berperan dalam peningkatan mutu tersebut. Dan yang berperan dalam peningkatan profesional kepala sekolah adalah pengawas sekolah yang juga merupakan pemimpin pendidikan yang bersama-sama kepala sekolah memiliki tanggung jawab terhadap perkembangan sekolah. Upaya peningkatan keprofesionalan kepala sekolah tidak akan terwujud begitu saja tanpa adanya motivasi dan adanya kesadaran dari dalam diri kepala sekolah tersebut serta semangat mengabdi yang akan melahirkan visi kelembagaan maupun kemampuan konsepsional yang jelas.
\end{abstract}

Kata kunci: Profesional, kepemimpinan, dan kepala sekolah 
Vol. V, No. 1, April 2017

\section{A. Pendahuluan}

Sejalan dengan tantangan kehidupan global, pendidikan merupakan hal yang sangat penting karena pendidikan salah satu penentu mutu Sumber Daya Manusia. Dimana dewasa ini keunggulan suatu bangsa tidak lagi ditandai dengan melimpahnya kekayaan alam, melainkan pada keunggulan Sumber Daya Masnusia (SDM) berkorelasi positif dengan mutu pendidikan, mutu pendidikan sering diindikasikan dengan kondisi yang baik, memenuhi syarat, dan segala komponen yang harus terdapat dalam pendidikan, komponenkomponen tersebut adalah masukan, proses keluaran, tenaga kependidikan, sarana dan prasarana serta biaya.

Mutu pendidikan tercapai apabila masukan, proses, keluaran, guru, Sarana dan prasarana serta biaya memenuhi syarat tertentu. Namun dari beberapa komponen tersebut yang banyak berperan adalah tenaga kependidikan yang bermutu yaitu yang mampu menjawab tantangan-tantangan dengan cepat dan tanggung jawab. Tenaga kependidikan pada masa mendatang akan semakin kompleks, sehingga menuntut tenaga kependidikan untuk senantiasa melakukan berbagai peningkatan dan penyesuaian penguasaan kompetensinya. Pendidikan yang bermutu sangat membutuhkan tenaga kependidikan yang profesional.

Tenaga kependidikan mempunyai peran yang sangat strategis dalam pembentukan pengetahuan, keterampilan, dan karakter peserta didik. Oleh karena itu tenaga kependidikan yang profesional akan melaksanakan tugasnya secara profesional sehingga menghasilkan tamatan yang lebih bermutu. Menjadi tenaga kependidikan yang 
profesional tidak akan terwujud begitu saja tanpa adanya upaya meningkatkannya, adapun salah satu cara untuk mewujudkannya adalah dengan pengembangan profesional ini membutuhkan dukungan dari pihak yang mempunyai peran penting dalam hal ini kepala sekolah, dimana kepala sekolah merupakan pemimpin pendidikan yang sangat penting karena kepala sekolah berhubungan langsung dengan pelaksanaan program pendidikan di sekolah.

Ketercapaian tujuan sangat bergantung pada kecakapan dan kebijaksanaan kepemimpinan kepala sekolah yang merupakan salah satu pemimpin pendidikan. Karena kepala sekolah merupakan seorang pejabat profesional dalam organisasi sekolah yang bertugas mengatur semua sumber organisasi dan bekerja sama dengan guru-guru dalam mendidik siswa untuk mencapai tujuan pendidikan. Dengan keprofesionalan kepala sekolah ini pengembangan profesionalisme kependidikan mudah dilakukan karena sesuai dengan fungsinya, kepala sekolah memahami kebutuhan sekolah yang ia pimpin sehingga kompentensi guru tidak hanya mandeg pada kompetensi yang ia miliki sebelumnya, melainkan bertambah dan berkembang dengan baik sehingga profesinalisme guru akan terwujud. Karena tenaga kependidikan profesional tidak hanya menguasai bidang ilmu, bahan ajar, dan metode yang tepat, akan tetapi mampu memotivasi peserta didik, memiliki pengetahuan yang tinggi dan wawasan yang luas terhadap dunia pendidikan. Profesionalisme tenaga kependidikan juga secara konsisten menjadi salah satu faktor terpenting dari mutu pendidikan. Tenaga kependidikan yang profesional mampu membelajarkan murid secara efektif sesuai dengan kendala sumber 
Vol. V, No. 1, April 2017

daya dan lingkungan. Namun untuk menghasilkan guru yang profesional juga bukanlah tugas yang mudah. Guru harus lebih dinamis dan kreatif dalam mengembangkan proses pembelajaran siswa. Agar proses pendidikan dapat berjalan dengan efisien, guru dituntut memiliki kompetensi yang memadai, baik dari segi jenis maupun isinya.

Namun banyak faktor penghambat tercapainya kualitas keprofesionalan kepemimpinan kepala sekolah seperti proses pengangkatan tidak transparan, rendahnya mental kepala sekolah yang ditandai dengan kurangnya motivasi dan semangat, serta kurangnya disiplin dalam melakukan tugas dan seringnya datang terlambat, wawasan kepala sekolah yang masih sempit, serta banyak faktor penghambat lainnya yang menghambat tumbuhnya kepala sekolah yang profesional untuk meningkatkan kualitas pendidikan. Ini mengimplikasikan rendahnya produktivitas kerja kepala sekolah yang berimplikasi juga pada mutu (input, proses dan output).

\section{B. Pembahasan}

Paradigma baru manajemen pendidikan dalam rangka meningkatkan kualitas secara efektif dan efisien, perlu didukung oleh Sumber Daya Manusia (SDM) yang berkualitas. Dalam hal ini, pengembangan SDM merupakan proses peningkatan kemampuan manusia agar mampu melakukan pilihan-pilihan. Proses pengembangan SDM tersebut harus menyentuh berbagai bidang kehidupan yang tercermin dalam pribadi pemimpin, termasuk pemimpin pendidikan seperti kepala sekolah. 
Kepala sekolah merupakan salah satu komponen pendidikan yang paling berperan dalam meningkatkan kualitas pendidikan. Sebagaimana dikemukakan dalam pasal 12 ayat 1 PP 28 tahun 1990 bahwa: kepala sekolah bertanggung jawab atas penyelenggaraan kegiatan pendidikan, administrasi sekolah, pembinaan tenaga kependidikan lainnya, dan pendayagunaan serta pemeliharaan sarana dan prasarana.

Kepala sekolah merupakan motor penggerak, penentu kebijakan sekolah yang akan menentukan bagaimana tujuan sekolah dan pendidikan pada umumnya direalisasikan.

1. Pengertian Profesionalisme, kepemimpinan, dan kepala sekolah a. Profesionalisme

Menurut Kusnandar, Profesionalisme adalah kondisi, arah, nilai tujuan, dan kualitas suatu keahlian dan kewenangan yang berkaitan dengan mata pencaharian seseorang. ${ }^{1}$ Selanjutnya menurut Muhammad Surya mengatakan bahwa profesionalisme adalah sebutan yang mengacu pada sikap mental dalam bentuk komitmen dari para anggota suatu profesi untuk senantiasa mewujudkan dan meningkatkan kualitas profesionalnya. $^{2}$ Sementara Sudarwan Danim mendefinisikan bahwa Profesionalisme adalah komitmen para anggota suatu profesi untuk kemampuan profesionalnya dan terus menerus mengembangkan strategi-strategi yang digunakannya dalam

\footnotetext{
${ }^{1}$ Kusnandar, Guru Profesional, ( Jakarta: PT Raja Grafindo, 2007), h. 46

${ }^{2}$ Muhammad Surya, Organisasi Profesi, Kode Etik dan Dewan Kehormatan Guru, (Bandung: Rosdakarya,2007), h. 214
} 
melakukan pekerjaan sesuai dengan profesinya itu. ${ }^{3}$ Kemudian Freidson dalam Syaiful Sagala mengemukakan bahwa yang dimaksud dengan profesionalisme adalah sebagai komitmen untuk ide-ide profesional dan karir. ${ }^{4}$

Jadi dapat disimpulkan bahwa profesionalisme adalah suatu bentuk komitmen para anggota suatu profesi untuk selalu meningkatkan dan mengembangkan kompetensinya yang bertujuan agar kualitas keprofesionalannya dapat tercapai secara berkesinambungan.

b. Kepemimpinan

Kepemimpinan merupakan salah satu faktor yang sangat penting dalam suatu organisasi karena sebagian besar keberhasilan dan kegagalan suatu organisasi ditentukan oleh kepemimpinan dalam organisasi tersebut. Pentingya kepemimpinan seperti yang dikemukakan oleh James M. Black yang dikutip oleh Sadili Samsudin yang dimaksud dengan kepemimpinan adalah kemampuan meyakinkan dan menggerakkan orang lain agar mau bekerja sama dibawah kepemimpinannya sebagai suatu tim untuk mencapai suatu tujuan tertentu. ${ }^{5}$

3 Sudarwan Danim, Inovasi Pendidikan Dalam Upaya Peningkatan Profesionalisme Tenaga Kependidikan, (Bandung: CV Pustaka Setia, 2002), h. 23

${ }^{4}$ Syaiful Sagala, Administrasi Pendidikan Kontemporer, ( Bandung: Alfabeta, 2005), h. 199

5 Sadili Samsudin, Manajemen Sumber Daya Manusia, (Bandung: Pustaka Setia, 2006), h. 287 
Sementara menurut R. Soekarto Indrafachrudi mengartikan kepemimpinan adalah suatu kegiatan dalam membimbing suatu kelompok sedemikian rupa sehingga tercapailah tujuan itu. ${ }^{6}$ Kemudian menurut Maman Ukas kepemimpinan adalah kemampuan yang dimiliki oleh seseorang untuk dapat mempengaruhi orang lain, agar ia mau berbuat sesuatu yang dapat membantu pencapaian suatu maksud dan tujuan tertentu. ${ }^{7}$ Sedangkan George R. Terry dalam Miftah Thoha mengartikan bahwa kepemimpinan adalah aktivitas untuk mempengaruhi orang-orang supaya diarahkan untuk mencapai tujuan organisasi. ${ }^{8}$

Berdasarkan beberapa definisi tersebut dapat disimpulkan bahwa kepemimpinan adalah kemampuan yang dimiliki seseorang dalam mempengaruhi orang lain untuk mau bekerja sama agar mau melakukan tindakan dan perbuatan dalam mencapai tujuan bersama.

c. Kepala sekolah

Kepala sekolah berasal dari dua kata yaitu kepala dan sekolah. Kata kepala dapat diartikan sebagai ketua atau pemimpin suatu organisasi atau sebuah lembaga. Sedangkan sekolah adalah sebuah lembaga dimana menjadi tempat menerima dan memberi pelajaran. Jadi secara umum kepala

\footnotetext{
${ }^{6}$ R. Soekarto Indrafachrudi, Bagaimana Memimpin Sekolah Yang Efektif,( Bogor: Ghalia Indonesia, 2006), h. 2

${ }^{7}$ Maman Ukas, Manajemen, ( Bandung; Agini, 2004), h. 268

8 Miftah Thoha, Kepemimpinan Dalam Manajemen, (Jakarta: Raja Grafindo, 2003), h.5
} 
Vol. V, No. 1, April 2017

sekolah dapat diartikan pemimpin sekolah atau suatu lebaga dimana tempat menerima dan memberi pelajaran.

Menurut Wahjosumijo bahwa kepala sekolah adalah seorang tenaga fungsional guru yang diberi tugas untuk memimpin suatu sekolah dimana diselenggarakan proses belajar mengajar, atau tempat dimana terjadinya interaksi antara guru yang memberikan pelajaran dan murid yang menerima pelajaran.9 Sementara Rahman dkk, mengungkapkan bahwa kepala sekolah adalah seorang guru (jabatan fungsional) yang diangkat untuk menduduki jabatan struktural (kepala sekolah) di sekolah.10 Adapun menurut Sudarwan Danim, kepala sekolah adalah guru yang mendapatkan tugas tambahan sebagai kepala sekolah.11

Kepala sekolah merupakan unsur yang sangat berpengaruh terhadap segala aktivitas disuatu lembaga pendidikan. Kepala sekolah yang baik akan bersikap dinamis untuk menyiapkan berbagai macam program pendidikan, bahkan tinggi rendahnya mutu sebuah sekolah ditentukan oleh kepemimpinan di sekolah. Kepala sekolah adalah pemimpin yang berhubungan langsung dengan sekolah. Oleh karena itu, kepala sekolah harus berupaya mewujudkan kondisi sosial yang

9 Wahjosumidjo, Kepemimpinan Kepala Sekolah, (Jakarta: Raja Grafindo Persada, 2002), h. 83

${ }^{10}$ Rahman dkk, Peran Strategi Kepala Sekolah Dalam Meningkatkan Mutu Pendidikan , (Jatinangor: Alqaprint, 2006), h. 106

11 Sudarwan Danim, Inovasi Pendidikan Dalam Upaya Peningkatan Profesionalisme tenaga Kependidikan, (Bandung: Pustaka Setia, 2010), cet. Ke-2, h. 145 
mendukung kegiatan lembaga pendidikan yang dipimpinnya. ${ }^{12}$ Selain itu, kepala sekolah adalah subjek yang paling banyak terlibat dalam aplikasi inovasi manajemen pendidikan di tingkat makro, sehingga kepala sekolah merupakan faktor kunci efektif tidaknya suatu sekolah karena kepala sekolah memainkan peranan yang sangat penting dalam keseluruhan spektrum pengelolaan sekolah. ${ }^{13}$

Kepala sekolah harus memiliki jiwa kepemimpinan untuk mengatur para guru, pegawai sekolah, sarana prasarana dan lain sebagainya. Dalam hal ini, kepala sekolah tidak hanya mengatur para guru saja, melainkan juga sarana prasarana sekolah, siswa, hubungan sekolah dengan masyarakat dan orang tua siswa. Tercapai tidaknya tujuan sekolah sepenuhnya bergantung pada kebijaksanaan yang diterapkan oleh kepala sekolah.

Menurut Pidarta sebagaimana dikutip oleh E. Mulyasa dalam bukunya Manajemen Berbasis Sekolah Konsep Strategi dan Implementasi. Mengemukakan tiga macam keterampilan yang harus dimiliki oleh kepala sekolah untuk menyukseskan kepemimpinannya. Ketiga keterampilan tersebut adalah keterampilan konseptual, yaitu keterampilan untuk memahami dan mengoperasikan organisasi; keterampilan manusiawi, yaitu keterampilan untuk bekerja sama, memotivasi dan memimpin; serta teknik ialah keterampilan dalam menggunakan

${ }^{12}$ Sulistyorini, Manajemen Pendidikan Islam Konsep, Strategi, dan Aplikasi, (Yogyakarta : Teras, 2009) h.167-168

13 Sudarwan Danim, Visi Baru Manajemen Sekolah dari Unit Birokrasi ke Lembaga Akademik, (Jakarta : PT Bumi Aksara, 2012), h. 97 
pengetahuan, metode, teknik, serta perlengkapan untuk menyelesaikan tugas tertentu. Lebih lanjut dikemukakan bahwa untuk memiliki kemampuan, terutama keterampilan konsep, para kepala sekolah diharapkan melakukan kegiatan-kegiatan berikut:

1). Senantiasa belajar dari pekerjaan sehari-sehari terutama dari cara kerja para guru dan pegawai sekolah lainnya.

2). Melakukan observasi kegiatan manajemen secara terencana;

3). Membaca berbagai hal yang berkaitan dengan kegiatankegiatan yang sedang dilaksanakan;

4). Memanfaatkan hasil-hasil penelitian orang lain;

5). Berpikir untuk masa yang akan datang, dan;

6). Merumuskan ide-ide yang dapat diuji cobakan. Selain itu, kepala sekolah harus dapat menerapkan gaya kepemimpinan yang efektif sesuai dengan situasi dan kebutuhan serta motivasi para guru dan pekerjaan lain. 14

Berdasarkan beberapa pengertian di atas dapat disimpulkan bahwa kepala sekolah adalah seorang guru yang mempunyai kemampuan untuk memimpin segala sumber daya yang ada pada suatu sekolah sehingga dapat didayagunakan secara maksimal untuk mencapai tujuan bersama. Jadi profesionalisme kepemimpinan kepala sekolah berarti suatu

14 Sudarwan Danim, Visi Baru Manajemen Sekolah dari Unit Birokrasi ke Lembaga Akademik, (Jakarta : PT Bumi Aksara, 2012), h. 97 
bentuk komitmen para anggota suatu profesi untuk selalu meningkatkan dan mengembangkan kompetensinya yang bertujuan agar kualitas keprofesionalannya dapat terlaksana dengan baik dalam menjalankan dan memimpin segala sumber daya yang ada pada suatu sekolah untuk mau bekerja sama dalam mencapai tujuan bersama.

2. Profesionalisme Kepemimpinan Kepala Sekolah

Kepala sekolah merupakan salah satu komponen pendidikan yang paling berperan dalam meningkatkan kualitas pendidikan. Untuk itu kepala sekolah harus mengetahui tugas-tugas yang harus dilaksanakannya. Adapun tugas-tugas dari kepala sekolah seperti dikemukakan Wahjosumidjo adalah sebagai berikut:

a. Kepala sekolah bertanggung jawab dan mempertanggung jawabkan. Kepala sekolah bertindak dan bertanggung jawab atas segala tindakan yang dilakukan oleh bawahannya. Perbuatan yang dilakukan oleh para guru, siswa, staf dan orang tua siswa tidak dapat dilepaskan dari tanggung jawab kepala sekolah.

b. Dengan waktu dan sumber yang terbatas seorang kepala harus mampu menghadapi berbagai persoalan. Dengan segala keterbatasan, seorang kepala sekolah harus dapat mengatur pemberian tugas secara cepat serta dapat memprioritaskan bila terjadi konflik antara kepentingan bawahan dengan kepentingan sekolah.

c. Kepala sekolah harus berfikir secara analitik dan konsepsional. Kepala sekolah harus dapat memecahkan 
persoalan melalui satu analisis, kemudian menyelesaikan persoalan dengan solusi yang fleksibel serta harus dapat melihat setiap tugas sebagai satu keseluruhan yang saling berkaitan.

d. Kepala sekolah adalah seorang mediator atau juru penengah. Dalam lingkungan sekolah sebagai suatu organisasi didalamnya terdiri dari manusia yang mempunyai latar belakang yang berbeda-beda yang bisa menimbulkan konflik untuk itu kepala sekolah harus jadi penengah dalam konflik tersebut.

e. Kepala sekolah adalah seorang politisi. Kepala sekolah harus dapat membangun hubungan kerja sama melalui pendekatan persuasif dan kesepakatan (compromise). Peran politisi kepala sekolah dapat berkembang secara efektif, apabila: (1) dapat dikembangkan prinsip jaringan saling pengertian terhadap kewajiban masing-masing, terbentuknya aliansi atau koalisi, seperti organisasi profesi, OSIS, BP3, dan Sebagainya, (3) terciptanya kerjasama (cooperation) dengan berbagai pihak, sehingga berbagai macam aktivitas dapat dilaksanakan.

f. Kepala sekolah adalah seorang diplomat. Dalam berbagai macam pertemuan kepala sekolah adalah wakil resmi sekolah yang dipimpinnya.

g. Kepala sekolah mengambil keputusan-keputusan sulit. Tidak ada satu organisasipun yang berjalan mulus tanpa problem. Demikian pula sekolah sebagai suatu organisasi 
tidak luput dari persoalan dan kesulitan-kesulitan. Dan apabila terjadi kesulitan-kesulitan kepala sekolah diharapkan berperan sebagai seorang yang dapat menyelesaikan persoalan yang sulit tersebut. ${ }^{15}$

Dalam menjalankan kepemimpinannya, selain tahu dan paham tugasnya sebagai pemimpin yang tidak kalah pentingnya dari semua itu adalah sebagai seorang kepala sekolah hendaknya memahami dan mengetahui perannya. Adapun peran-peran kepala sekolah seperti yang diungkapkan oleh wahjosumidjo adalah:

a. Peranan hubungan antar perseorangan

Peranan hubungan antar perseorangan:

1) Figurehead, berarti lambang dengan pengertian kepala sekolah sebagai lambang sekolah.

2) Kepemimpinan (Leadership). Kepala sekolah adalah pemimpin untuk menggerakkan seluruh sumber daya yang ada di sekolah sehingga dapat melahirkan etos kerja dan produktivitas yang tinggi untuk mencapai tujuan

3) Penghubung (Liasion). Kepala sekolah menjadi penghubung antara kepentingan kepala sekolah dengan lingkungan di luar sekolah. Sedangkan secara internal kepala sekolah menjadi perantara guru, staf, dan siswa. 
b. Peranan informasional

1) Sebagai monitor. Kepala sekolah selalu mengadakan pengamatan terhadap lingkungan karena kemungkinan adanya informasi-informasi yang berpengaruh terhadap sekolah

2) Sebagai disseminator. Kepala sekolah bertanggung jawab untuk menyebarluaskan dan membagi-bagi informasi kepada para guru, staf, dan orang tua murid.

3) Spokesman. Kepala sekolah menyebarkan informasi kepada lingkungan di luar yang dianggap perlu.

c. Sebagai pe ngambil keputusan

1) Entrepreneur. Kepala sekolah selalu berusaha memperbaiki penampilan sekolah melalui berbagai macam pemikiran program-program yang baru serta melakukan survei untuk mempelajari berbagai persoalan yang timbul di lingkungan sekolah

2) Orang yang memperhatikan gangguan (Disturbance handler). Kepala sekolah harus mampu mengantisipasi gangguan yang timbul dengan memperhatikan situasi dan ketepatan dalam mengambil keputusan.

3) Orang yang menyediakan segala sumber (aResource Allocater). Kepala sekolah bertanggung jawab untuk menentukan dan meneliti siapa yang akan memperoleh atau menerima kebutuhan sekolah. ${ }^{16}$ 
3. Kiat suskes menjadi kepala sekolah profesional

Memiliki kepala sekolah profesional tentu menjadi harapan semua orang, terutama pihak-pihak yang berkaitan dengan dunia pendidikan. Namun, untuk menjadi kepala sekolah profesional, seorang harus melewati perjuangan keras dan semangat belajar yang tidak kenal lelah. Kepala sekolah profesional harus mempunyai kepribadian positif- konstruktif bagi lahirnya kemajuan demi kemajuan. Terkait hal itu, berikut adalah beberapa tips efektif untuk menjadi kepala sekolah profesional

a. Memberikan keteladanan

b. Cerdas memilih bawahan

c. Berorientasi pemberdayaan

d. Mengedepankan kaderisasi

e. Menjaga keseimbangan

f. Aktif bekerja sama dengan pihak lain

g. Kreatif mengembangkan kemandirian dana

h. Proaktif meningkatkan diversifikasi

i. Rutin melakukan Supervisi

j. Menciptakan transparansi dan akuntabilitas

k. Memberikan jaminan masa depan. ${ }^{17}$

Disamping itu ada beberapa hal yang harus dilakukan kepala sekolah selaku pemimpin, yaitu:

a. Banyak menawarkan apa dan mengapa

b. Berpikir dan bertindak jangka panjang manusia

17 Jamal Ma'mur Asmani, Tips Menjadi Kepala Sekolah Profesional, (Yogyakarta: DIVA Press, 2012), h. 229 
Vol. V, No. 1, April 2017

c. Bersikap demokratis

d. Membolehkan

e. Mengembangkan

f. Menantang

g. Orisinal (autentik)

h. Inovasi

i. Mengarahkan kebijakan

j. Luwes

k. Menganggap resiko sebagai peluang

1. Menjadi atasan

m. Mengerjakan sesuatu secara tepat (keefektifan). ${ }^{18}$

4. Kewajiban Kepala sekolah

Sebagai seorang pemimpin, kewajiban menghidupkan organisasi melekat pada diri kepala sekolah. Secara lebih jelas Dedy Mulyasana merinci kewajiban kepala sekolah sebagai berikut:

a. Menjabarkan visi kedalam misi target mutu

b. Merumuskan tujuan dan target yang akan dicapai

c. Menganalisis tantangan, peluang, kekuatan, dan kelemahan sekolah/madrasah

d. Membuat rencana kerja strategis dan rencana kerja tahunan untuk pelaksanaan peningkatan mutu

e. Bertanggung jawab dalam membuat keputusan anggaran sekolah/madrasah 
f. Melibatkan guru dan komite sekolah dalam pengambilan keputusan penting sekolah/madrasah

g. Berkomunikasi untuk menciptakan dukungan intensif dari orang tua/wali siswa dan masyarakat

h. Menjaga dan meningkatkan motivasi kerja pendidik dan tenaga kependidikan dengan menggunakan sistem pemberian penghargaan atas prestasi serta sanksi atas pelanggaran peraturan dan kode etik

i. Menciptakan lingkungan pembelajaran yang efektif bagi siswa

j. Bertanggung jawab atas perencanaan partisipatif mengenai pelaksanaan kurikulum

k. Melaksanakan dan merumuskan program supervise

1. Meningkatkan mutu pendidikan

m. Memberi teladan dan menjaga nama baik lembaga, profesi, dan kedudukan sesuai dengan kepercayaan yang diberikan kepadanya

n. Memfasilitasi pengembangan, penyebarluasan, dan pelaksanaan visi pembelajaran yang dikomunikasikan dengan baik dan didukung oleh komunitas sekolah

o. Membantu, membina dan mempertahankan lingkungan sekolah serta program pembelajaran yang kondusif bagi proses belajar siswa dan pertumbuhan profesional para guru dan tenaga kependidikan 
Vol. V, No. 1, April 2017

p. Menjamin manajemen organisasi dan pengoperasian sumber daya sekolah untuk menciptkan lingkungan belajar yang aman, sehat, efisien, dan efektif

q. Menjalin kerjasama dengan orang tua/wali siswa serta masyarakat, dan komite sekolah menanggapi kepentingan serta kebutuhan komunitas yang beragam, dan memobilisasi sumber daya masyarakat.

r. Kepala sekolah dapat mendelegasikan sebagian tugas dan kewenangan kepada wakil kepala sekolah sesuai dengan bidangnya. ${ }^{19}$

Seperti halnya diungkapkan di muka, banyak faktor penghambat tercapainya kualitas keprofesionalan kepemimpinan kepala sekolah, Seperti proses pengangkatan yang tidak transparan, rendahnya mental kepala sekolah yang ditandai dengan kurangnya motivasi dan semangat serta kurangnya disiplin dalam melakukan tugas dan seringnya datang terlambat, wawasan kepala sekolah yang masih sempit, serta banyak faktor penghambat lainnya yang menghambat tumbuhnya kepala sekolah yang profesional untuk meningkatkan kualitas pendidikan. Ini mengimplikasikan rendahnya produktivitas kerja kepala sekolah yang berimplikasi juga pada mutu (input, proses, dan outpout)

Berdasarkan masalah-masalah tersebut, adapun pemecahannya adalah

a. Pembinaan kemampuan profesional kepala sekolah

19 Dedy Mulyana, Pendidikan Bermutu Dan Berdaya Saing, (Bandung: Remaja Rosdakarya, 2011), cet. 1, h. 117-118 
Wadah-wadah yang telah dikembangkan dalam pembinaan kemampuan profesional kepala sekolah adalah Musyawarah Kepala Sekolah (MKS), Kelompok Kerja Kepala Sekolah (KKKS), Pusat Kegiatan Kepala Sekolah (PKKS). Disamping itu, peningkatan dapat dilakukan melalui pendidikan, dengan program sarjana atau pasca sarjana bagi para kepala sekolah dengan bidang keahliannya, sehingga tidak terlepas dari koridor disiplin ilmu masing-masing.

b. Revitalisasi MKKS

Melalui MKKS dapat dipikirkan bagaimana menyiasati kurikulum yang padat dan mencari alternatif pembelajaran yang tepat serta menemukan berbagai variasi metode dan variasi media untuk meningkatkan kualitas pembelajaran.

Dengan mengefektifkan MKKS semua kesulitan dan permasalahan yang dihadapi oleh guru dan kepala sekolah dalam kegiatan pendidikan dapat dipecahkan, dan diharapkan dapat meningkatkan mutu pendidikan di sekolah.

c. Peningkatan disiplin

Dalam menumbuhkan kepala sekolah profesional dalam paradigma baru manajemen pendidikan di sekolah diperlukan adanya peningkatan disiplin untuk menciptakan iklim sekolah yang lebih kondusif dan dapat memotivasi kerja, serta menciptakan budaya kerja dan budaya disiplin para tenaga kependidikan dalam melakukan tugasnya di sekolah. 
Vol. V, No. 1, April 2017

d. Pembentukan kelompok diskusi profesi

Kelompok diskusi profesi dibentuk untuk mengatasi tenaga pendidikan yang kurang semangat dalam melakukan tugas-tugas kependidikan di sekolah yang melibatkan pengawas sekolah, komite sekolah atau orang lain yang ahli dalam memecahkan masalah yang dihadapi kepala sekolah dan tenaga kependidikan.

e. Peningkatan layanan perpustakaan dan penambahan koleksi

Salah satu sarana peningkatan profesionalisme kepala sekolah adalah tersedianya buku yang dapat menunjang kegiatan sekolah dalam mendorong visi menjadi aksi karena akan sangat sulit dapat mengembangkan dan meningkatkan profesionalisme kepala sekolah jika tidak ditunjang oleh sumber belajar yang memadai.

Selain itu kepala sekolah harus memiliki visi dan misi, serta strategi manajemen pendidikan secara utuh yang berorientasi kepada mutu. Strategi ini dikenal dengan Manajemen Mutu Terpadu (MMT) atau kalau dunia bisnis dikenal dengan nama Total Quality Management (TQM). Yang merupakan usaha sistematis dan terkoordinasi untuk secara terus menerus memperbaiki kualitas layanan.

\section{Penutup}

Kepala sekolah merupakan pemimpin formal yang tidak bisa diisi oleh orang-orang tanpa didasarkan atas pertimbangan tertentu. Untuk itu kepala sekolah bertanggung jawab melaksanakan fungsi-fungsi 
kepemimpinan baik yang berhubungan dengan pencapaian tujuan pendidikan maupun dalam menciptakan iklim sekolah yang kondusif yang menumbuhkan semangat tenaga kependidikan maupun peserta didik. Dengan kepemimpinan kepala sekolah inilah, kepala sekolah diharapkan dapat memberikan dorongan serta memberikan kemudahan untuk kemajuan serta dapat memberikan inspirasi dalam proses pencapaian tujuan.

Kepala sekolah diangkat melalui prosedur serta persyaratan tertentu yang bertanggung jawab atas tercapainya tujuan pendidikan melalui upaya peningkatan profesionalisme tenaga kependidikan yang mengimplikasikan meningkatnya prestasi peserta didik. Kepala sekolah yang professional akan berfikir untuk membuat perubahan tidak lagi berfikir bagaimana suatu perubahan sebagaimana adanya sehingga tidak terlindas oleh perubahan tersebut. Untuk mewujudkan kepala sekolah yang profesional tidak semudah membalikkan telapak tangan, semua itu butuh proses yang panjang.

Sesuai dengan perkembangan ilmu pengetahuan, teknologi, seni dan budaya yang diterapkan dunia pendidikan, sehingga menuntut penguasaan kepala sekolah secara profesional. Untuk itu kepala sekolah dihadapkan pada tantangan untuk melaksanakan pengembangan pendidikan secara terarah dan berkesinambungan.

Peningkatan profesionalisme kepala sekolah perlu dilaksanakan secara berkesinambungan dan terencana dengan melihat permasalahanpermasalahan dan keterbatasan yang ada. Sebab kepala sekolah merupakan pemimpin pendidikan yang juga bertanggung jawab dalam meningkatkan profesionalisme tenaga kependidikan lainnya. Kepala 
Vol. V, No. 1, April 2017

sekolah yang profesional akan mengetahui kebutuhan dunia pendidikan, dengan begitu kepala sekolah akan melakukan penyesuaian-penyesuaian agar prendidikan berkembang dan maju sesuai dengan kebutuhan pembangunan serta kemajuan ilmu pengetahuan dan teknologi. 
Nurmadiah

\section{DAFTAR PUSTAKA}

E. Mulyasa, 2006, Menjadi Kepala Sekolah Profesional, Bandung: PT. Remaja Rosdakarya.

Kusnandar, 2007, Guru Profesional, Jakarta: Raja Grafindo.

Maman Ukas, 2004, Manajemen, Bandung: Agini.

Miftah Toha, 2003, Kepemimpinan Dalam Manajemen, Jakarta: PT: Raja Grafindo.

Muhammad Surya, Organisasi Profesi, kode Etik dan Dewan Kehormatan Guru, Bandung: pustaka Setia.

R. Soekarto Indrafachrudi, 2006, Bagaimana Memimpin Sekolah Yang Efektif, Bogor: Ghalia Indonesia.

Rahman, dkk, 2006, Peran Strategi Kepala Sekolah Dalam Meningkatkan Mutu Pendidikan, Jatinangor: Alqaprint.

Sadili Samsudin, 2006, Manajemen Sumber Daya Manusia, Bandung: CV Pustaka Setia.

Sudarwan Danim, 2002, Inovasi Pendidikan Dalam Upaya Peningkatan Profesionalisme Tenaga Kependidikan, Bandung: CV Pustakan Setia.

Syaiful Sagala, 2002, Administrasi Pendidikan Kontemporer, Bandung: Alfabeta.

Wahjosumidjo, 2002, Kepemimpinan Kepala Sekolah, Jakarta: Raja Grafindo Persada. 
106 | Jurnal Al-Afkar

Vol. V, No. 1, April 2017 